\title{
Complement system in synovial fluids from patients with rheumatoid arthritis
}

\author{
HIDEKICHI SONOZAKI* AND MOTOMICHI TORISU \\ From the Department of Orthopaedic Surgery, Faculty of Medicine, Tokyo University, and the Virology \\ Division, National Cancer Center Research Institute, Tokyo, Japan
}

Immunological processes have been thought to play a role in rheumatoid arthritis, but no conclusive evidence has yet been obtained. Rheumatoid factor (RA factor) is known to be an antibody-like protein frequently found in the sera of patients with rheumatoid arthritis, but it has not been proved that it has any immediate relationship with the inflammatory processes of the disease, and the specific 'auto-antibody' has not yet been detected.

However, many biological phenomena, which take place in immunological reactions are caused not only by the specific antibody but also by nonspecific serum factors such as those of the complement system or the fibrinolysin system.

The complement system is a group of serum proteins consisting of nine components designated $\mathrm{C} 1, \mathrm{C} 4, \mathrm{C} 2, \mathrm{C} 3, \mathrm{C} 5, \mathrm{C} 6, \mathrm{C} 7, \mathrm{C} 8$, and $\mathrm{C} 9$ (Nelson, Jensen, Gigli, and Tamura, 1966; Müller-Eberhard, 1965), which interact with antigen-antibody complexes in this sequence.

$\mathrm{Cl}$ is activated by antigen-antibody complexes and acquires esterase activity which destroys C4 and C2 (Lepow, Ratnoff, Rosen, and Pillemer, 1956). It also enhances the permeability of the walls of capillary vessels (Dias da Silva and Lepow, 1965).

$\mathrm{C} 4$ is a component which reacts with antigenantibody $\mathrm{C} 1$ complexes. It is identified antigenically as $\beta_{1 E}$ globulin (Müller-Eberhard and Biro, 1963).

C3 is activated by the effect of activated C4, C2 complexes (Müller-Eberhard, Polley, and Calcott, 1967) and acquires peptidase activity (Cooper and Becker, 1967). Activated C3 causes some important immunological reactions, such as immune adherence (Nishioka, 1963) and immune phagocytosis (Nelson, 1953). C3 is identified antigenically as $\beta_{1} \mathrm{C}$ globulin by immune electrophoresis (MüllerEberhard and Nilsson, 1960).

C3 and C5 are the components which participate in an anaphylatoxin generation, and are thought to play an important role in immune pathological procedures (Jensen, 1967; Dias da Silva and Lepow, 1966).
$\mathrm{C} 5, \mathrm{C} 6$, and $\mathrm{C} 7$ are said to take part in the formation of a chemotactic substance, causing accumulations of polymorphonucleocytes (Ward, Cochrane, and Miiller-Eberhard, 1966).

When all nine components of complement have reacted, immune cytolysis, such as immune haemolysis (Borsos, Dourmashkin, and Humphrey, 1964), the serum bactericidal reaction (Muschel and Treffers, 1956), and the lysis of certain tumour cells (Green, Barrow, and Goldberg, 1969), takes place.

The complement system thus plays very important roles in the inflammatory processes of immunological reactions.

It is interesting to clarify the state of the complement system in so-called immune diseases such as rheumatoid arthritis. In rheumatoid arthritis, the levels of complement activity in synovial fluids are said to be diminished compared with those in other joint diseases (Pekin and Zvaifler, 1964, Hedberg, 1963). In order further to explore the mechanisms of this intra-articular complement depletion in rheumatoid arthritis, the nine components of complement were measured. Some of them were shown to exist in inactivated forms in rheumatoid synovial fluids, suggesting the local utilization of the complement system in the development of this disease.

\section{Material and Methods}

\section{SYNOVIAL FLUIDS}

These were obtained from patients with rheumatoid arthritis, osteoarthritis, and other arthritides.

Nineteen patients with rheumatoid arthritis fulfilled the American Rheumatoid Association's criteria for definite or classical rheumatoid i.rthritis. They represented all degrees of disease activity, and had received many different therapeutic agents, including salicylates, phenylbutazone, gold salts, indomethacine, and corticosteroids.

Seventeen patients with osteoarthritis had a characteristic history of noninflammatory arthritis and typical radiological and synovial fluid findings.

Twelve patients with other arthritic conditions, including gouty, post-traumatic, and infectious arthritis, had acute arthritis and/or characteristic histories. 
Synovial fluids were obtained by aseptic aspiration of the suprapatellar pouch, immediately placed in an ice box, and then centrifuged at $0^{\circ} \mathrm{C}$. for $15 \mathrm{~min}$. at 3,000 rpm. The supernatant fluids were kept at $-70^{\circ} \mathrm{C}$. in an electric deep-freezer until the titrations were performed. Before titration, the synovial fluids were treated with 50 units hyaluronidase per ml. fluid at $37^{\circ} \mathrm{C}$. for $10 \mathrm{~min}$. This procedure had no effect on the complement system.

\section{DILUENTS}

$\mathrm{GVB}^{++}$(gelatin veronal buffer) containing $0 \cdot 1$ per cent. gelatin (Difco), $0.00015 \mathrm{M} \mathrm{Ca}^{++}$, and $0-0005 \mathrm{M} \mathrm{Mg}^{++}$ was prepared (Mayer, 1961). Glucose-GVB ++ (glucosegelatin veronal buffer; gl-GVB ${ }^{++}$) was made by mixing gelatin veronal buffer containing twice the usual amounts of $\mathrm{Ca}^{++}$and $\mathrm{Mg}^{++}$with an equal volume of 5 per cent. glucose in distilled water (Inoue and Nelson, 1965). Two different concentrations of ethylenediaminetetraacetate (EDTA)-GVB, containing 0.04 and $0.01 \mathrm{M}$ EDTA, were used.

\section{SHEEP ERYTHROCYTE (E), AMBOCEPTOR} (A), AND SENSITIZED SHEEP ERYTHROCYTE (EA)

The source and preparation of sheep erythrocyte (E), rabbit antibody to boiled stroma of sheep erythrocyte (A), and sensitized sheep erythrocyte (EA) are given by Mayer (1961).

\section{PREPARATION OF INTERMEDIATE COMPLEX}

Sensitized sheep erythrocytes with first and fourth

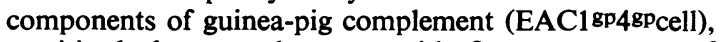
sensitized sheep erythrocytes with first component of guinea-pig (EAC18pcell) and human (EAC1 hucell) complement, and sensitized sheep erythrocytes with fourth component of guinea-pig (EAC48pcell) complement were prepared as described by Nelson and others (1966) and Nishioka and Linscott (1963).

Intermediate complex of sensitized sheep erythrocytes with first component of guinea-pig complement and fourth component of human complement (EAC1 gp4hucell) was prepared as follows: To EA cells suspended in gl-GVB ${ }^{++}$, were added 1,000 effective molecules per cell of $\mathrm{C} 1 \mathrm{gp}$. The mixture was incubated at $30^{\circ} \mathrm{C}$. for $20 \mathrm{~min}$. and $0^{\circ} \mathrm{C}$. for $20 \mathrm{~min}$. and then washed three times and resuspended in $\mathrm{gl}-\mathrm{GVB}^{++}\left(\mathrm{EAC1} \mathrm{gp}_{\text {cell }}\right)$. These EAC1gp cells were mixed with 500 effective molecules per cell of purified $\mathrm{C} 4 \mathrm{hu}$. The mixture was incubated at $37^{\circ} \mathrm{C}$. for $20 \mathrm{~min}$. and the cells were washed three times with gl-GVB ++ (EAC1 gp4hucell). The cells were stored at 0 to $2^{\circ} \mathrm{C}$. after the addition of 100 units penicillin and 100 $\mu \mathrm{g}$. streptomycin $/ \mathrm{ml}$. Before use, they were washed with suitable diluent to remove the antibiotics.

TITRATION OF COMPLEMENT REACTIVITY OF SYNOVIAL FLUID BY IMMUNE HAEMOLYSIS AND IMMUNE ADHERENCE

Haemolytic complement activity $\left(\mathrm{CH}_{50}\right)$ was measured according to the method of Mayer (1961) and immune adherence haemagglutination $\left(\mathrm{IA}_{50}\right)$ was performed according to the method of Nishioka (1963).
TITRATION OF C1, C4, AND C2 IN HUMAN SERUM AND SYNOVIAL FLUID

Stoichimetric titration of $\mathrm{C} 1, \mathrm{C} 4$, and $\mathrm{C} 2$ in all samples to be tested was performed essentially as described by Nelson and others (1966) and Mayer (1961).

Titration of $\mathrm{C} 4$ was performed as follows:

Sample dilutions, $\mathbf{0} \cdot 2 \mathrm{ml}$. in gl-GVB ${ }^{++}$, were incubated with $0.2 \mathrm{ml}$. EAC1 8 cell $\left(1 \times 10^{8} / \mathrm{ml}\right.$. $)$ for $10 \mathrm{~min}$. at $30^{\circ} \mathrm{C}$. $0 \cdot 2 \mathrm{ml}$ purified C2gp (100 eff. mole/cell) were then added and incubated for another $10 \mathrm{~min}$. at $30^{\circ} \mathrm{C}$., followed by the addition of $0.6 \mathrm{ml} .1: 37.5$ complementEDTA and further incubation at $37^{\circ} \mathrm{C}$. for $60 \mathrm{~min}$. Then $1.6 \mathrm{ml}$. cold $0.01 \mathrm{M}$ EDTA-GVB were added to each tube, thoroughly mixed, and centrifuged. Oxyhaemoglobin contents of the supernatants were measured at $414 \mathrm{~m} \mu$.

$\mathrm{C} 1$ and $\mathrm{C} 2$ were titrated employing EAC48pcell and EAC1 1844hucell (Tamura and Jensen, 1966) respectively.

\section{TITRATION OF OTHER COMPONENTS}

$\mathrm{C} 3, \mathrm{C} 5, \mathrm{C} 6, \mathrm{C} 7, \mathrm{C} 8$, and $\mathrm{C} 9$ were assayed by immune haemolysis according to the method of Nelson and others (1966), using the microtitre technique described by Torisu, Arata, Sonozaki, and Majima (1967), except that EAC1 $18 \mathrm{CP} 4$ hucell was used for $\mathrm{C} 3$ titration, because human $\mathrm{C} 3$ was more reactive with $\mathrm{EAC1}$ 8pC4hu $\mathrm{C} 2 \mathrm{gp}$ cell than with EAC18pC48pC28pcell (Shimada, Sekine, Mayumi, and Miyakawa, 1969).

\section{PURIFIED COMPONENTS OF COMPLEMENT}

The first component of guinea-pig ( $\mathrm{C} 1 \mathrm{gp})$ and human (C1 hu) complement was precipitated at $\mathrm{pH} 7 \cdot 5$, as described by Nelson and others(1966). Further purification was obtained by reprecipitation under the same conditions. The fourth component of human complement (C4hu) was separated from the remaining fraction during the separation of $\mathrm{C} 3$ inactivator as described by Torisu, Sonozaki, Shiraishi, and Nishioka (1968). It was purified from human serum using column chromatography on diethylaminoethyl (DEAE) cellulose and carboxymethyl (CM) cellulose followed by Pevikon C870 zone electrophoresis and Sephadex G-200 superfine gelfiltration. Highly purified $\mathrm{C} 4^{\text {hu }}$ was prepared in collaboration with Dr. M. Matsuura and Dr. S. Takizawa. Purifications of other guinea-pig components of complement were carried out by the method of Nelson and others (1966).

\section{PREPARATION OF ANTISERUM TO C $4^{\text {hu }}$}

Rabbit anti- $\beta_{1} E$ globulin antiserum was kindly prepared by Dr. S. Inai as follows:

$0.85 \mathrm{mg}$. crystallized egg albumin $(5 \times$ recrystallized, Nutritional Biochemicals Corporation, Cleveland, Ohio) was added to the equivalent dose of an antirabbit serum $(1 \mathrm{ml}$.) in the presence of $0.01 \mathrm{M}$ EDTA and the mixture was kept at $4^{\circ} \mathrm{C}$. for $24 \mathrm{hrs}$. The precipitate was obtained by centrifugation at $6,000 \mathrm{rpm}$ for $15 \mathrm{~min}$., and washed twice with $0.01 \mathrm{M}$ EDTA and twice with saline. The precipitate was resuspended in saline to contain 376 $\mu \mathrm{g} . \mathrm{N} / \mathrm{ml} .1 \mathrm{ml}$. of this immune complex was added to $1.4 \mathrm{ml} . \mathrm{Clgp}\left(1.8 \times 10^{11} \mathrm{eff}\right.$. mol $)$ in the presence of GVB-Ca ${ }^{++}$, and incubated at $30^{\circ} \mathrm{C}$. for $20 \mathrm{~min}$. After centrifugation, the precipitate was washed once with $\mathrm{GVB}^{-\mathrm{Ca}^{++}}{ }^{+}$, and resuspended in the original volume of 
$\mathrm{GVB}^{-\mathrm{Ca}^{++}}+1 \mathrm{ml}$. of this egg albumin-antiegg albuminC1-complexes was added to $2.5 \mathrm{mg}$. $\left(4 \cdot 3 \times 10^{13} \mathrm{eff}\right.$. mol) $\mathrm{C}^{\text {hu }}$ and incubated at $30^{\circ} \mathrm{C}$. for $30 \mathrm{~min}$. The precipitate was separated by centrifugation and the supernatant fluid was treated again with another $1 \mathrm{ml}$. of the same immune precipitate. The precipitate thus obtained was washed once with GVB-Ca ${ }^{++}$, and then treated with 0.04 EDTA-GVB to eliminate the first component of complement. By these procedures, $4.3 \times 10^{13}$ eff. mol C4hu was found to be exhausted with the addition of $4,000 \mu \mathrm{g} . \mathrm{N}$ of egg albumin-antiegg albumin complexes. The final product was resuspended in saline so as to contain $200 \mu \mathrm{g} . \mathrm{N} / \mathrm{ml}$. and used for the immunization.

The egg albumin-antiegg albumin-C4 complex, prepared as described above, was injected into two rabbits; three times intravenously and twice intradermally into the foot pad and dorsum, at intervals of 3 to 4 days. 10 days after the last injection, the rabbits were bled and the sera were collected. These antisera gave a single precipitin line against whole human serum and purified C4 upon immunoelectrophoresis and Ouchterlony's double diffusion test.

\section{PREPARATION OF ANTISERUM TO C $3^{\text {hu }}$}

Two rabbits were injected into the foot pad with $1 \mathrm{mg}$. highly purified $C 3^{\text {hu }}$ ( $\beta_{1} \mathrm{C}$ globulin) in complete Freund's adjuvant One week later, $0.5 \mathrm{mg}$. $\beta_{1 \mathrm{C}}$ globulin in complete Freund's adjuvant were injected subcutaneously. 3 weeks later the rabbits were bled and sera were obtained. These sera produced only $\beta_{1} \mathrm{C}\left(\beta_{1 \mathrm{~A}}\right)$ globulin precipitin line against whole human sera and purified $C 3^{\text {hu }}$ on immunoelectrophoresis and Ouchterlony's double diffusion test.

\section{$\beta_{1 \mathrm{C}}\left(\beta_{1 \mathrm{~A}}\right)$ GLOBULIN}

The amount of $\beta_{1 C}\left(\beta_{1 A}\right)$ globulin antigenicity was measured using Partigen plates from Behringwerke Co. Ltd.

\section{TOTAL PROTEIN CONCENTRATIONS}

These were measured by Biuret reaction.

\section{IMMUNOELECTROPHORESIS}

Immunoelectrophoretic analyses in 1 per cent. agar were performed by the micromethod of Scheidegger (1955) at a potential gradient of $5 \mathrm{~V} / \mathrm{cm}$. for $90 \mathrm{~min}$.

\section{LATEX-FIXATION TEST}

Rheumatoid factor in synovial fluids was tested with a kit for the RA test from Hyland Laboratory.

\section{GLASSWARE}

All glassware was cleaned by overnight immersion in bichromate sulphuric acid, followed by multiple rinses with tap water and distilled water.

\section{Results}

\section{Synovial fluid complement activities}

The diagnoses of joint disease, synovial fluid total protein concentrations, and complement activities are shown in Table I, II, and III.

The synovial fluid complement activities in osteoarthritis were relatively low, having a median value of $10 \cdot 1 \mathrm{CH}_{50}$ (Table I). The synovial fluid complement activities of the patients with gout, posttraumatic arthritis, or other forms of acute arthritis were significantly high, having a median value of $15 \cdot 1 \mathrm{CH}_{50}$ (Table II).

Thirteen synovial fluid complement values in nineteen patients with rheumatic arthritis revealed significantly low titres and in one-third the complement activity was less than $\mathbf{1} \mathbf{C H}_{50}$.

$\mathrm{CIA}_{50}$ values corresponded well with haemolytic complement activities in every case.

Table I Total protein concentrations and complement activities in synovial fluids of 17 osteoarthritis patients (Nos. 1-17)

\begin{tabular}{|c|c|c|c|c|c|c|}
\hline Case No. & $\operatorname{Sex}$ & $\begin{array}{c}\text { Age } \\
(y r s)\end{array}$ & $\begin{array}{l}\text { Total protein } \\
\text { concentration } \\
(g . / 100 \mathrm{ml} .)\end{array}$ & $\mathrm{CH}_{50}$ & $C I A_{50}$ & $\begin{array}{l}\text { Latex-fixation } \\
\text { test }\end{array}$ \\
\hline $\begin{array}{r}1 \\
2 \\
3 \\
4 \\
5 \\
6 \\
7 \\
8 \\
9 \\
10 \\
11 \\
12 \\
13 \\
14 \\
15 \\
16 \\
17\end{array}$ & $\begin{array}{l}\mathbf{M} \\
\mathbf{F} \\
\mathbf{F} \\
\mathbf{M} \\
\mathbf{M} \\
\mathbf{F} \\
\mathbf{F} \\
\mathbf{F} \\
\mathbf{F} \\
\mathbf{M} \\
\mathbf{F} \\
\mathbf{F} \\
\mathbf{F} \\
\mathbf{F} \\
\mathbf{F} \\
\mathbf{F} \\
\mathbf{M}\end{array}$ & $\begin{array}{l}61 \\
43 \\
55 \\
54 \\
54 \\
63 \\
48 \\
80 \\
50 \\
54 \\
65 \\
52 \\
59 \\
65 \\
64 \\
50 \\
54\end{array}$ & $\begin{array}{l}2 \cdot 1 \\
2 \cdot 9 \\
2 \cdot 1 \\
2 \cdot 0 \\
\text { NT } \\
\text { NT } \\
3 \cdot 1 \\
3 \cdot 0 \\
3 \cdot 3 \\
1 \cdot 4 \\
2 \cdot 4 \\
3 \cdot 6 \\
2 \cdot 7 \\
3 \cdot 5 \\
3 \cdot 5 \\
3 \cdot 3 \\
3 \cdot 4\end{array}$ & $\begin{array}{r}15.2 \\
1.0 \\
6.0 \\
5.9 \\
5.9 \\
7.0 \\
7.3 \\
13.1 \\
15.5 \\
3.0 \\
9.5 \\
12.0 \\
10.3 \\
15.1 \\
16 \cdot 2 \\
15.5 \\
14.6\end{array}$ & $\begin{array}{r}27 \\
2 \\
27 \\
14 \\
27 \\
40 \\
80 \\
80 \\
80 \\
8 \\
27 \\
80 \\
40 \\
80 \\
120 \\
80 \\
80\end{array}$ & $\begin{array}{l}= \\
= \\
= \\
= \\
= \\
= \\
= \\
= \\
=\end{array}$ \\
\hline
\end{tabular}


Table II Total protein concentrations and complement activities in synovial fluids of 12 patients (Nos 18 to 29) other than osteoarthritis and rheumatoid arthritis patients

\begin{tabular}{llclcccc}
\hline Case No. & Sex & $\begin{array}{c}\text { Age } \\
(\text { yrs })\end{array}$ & Diagnosis & $\begin{array}{c}\text { Total protein } \\
\text { concentration } \\
(\text { g./100ml. })\end{array}$ & $C_{50}$ & $I_{50}$ & $\begin{array}{c}\text { Latex-fixation } \\
\text { test }\end{array}$ \\
\hline 18 & M & 39 & Traumatic & $4 \cdot 9$ & $19 \cdot 1$ & 120 & - \\
19 & M & 38 & Traumatic & $5 \cdot 3$ & $15 \cdot 8$ & 240 & - \\
20 & M & 42 & Traumatic & $5 \cdot 1$ & $16 \cdot 3$ & 120 & - \\
21 & M & 40 & Traumatic & $4 \cdot 8$ & $17 \cdot 5$ & 240 & - \\
22 & M & 24 & Traumatic & $1 \cdot 4$ & $2 \cdot 6$ & 8 & - \\
23 & F & 23 & Traumatic & $2 \cdot 3$ & $16 \cdot 7$ & 27 & - \\
24 & M & 20 & Traumatic & $1 \cdot 9$ & $3 \cdot 2$ & 27 & - \\
25 & F & 21 & Infectious & $4 \cdot 8$ & $22 \cdot 1$ & 480 & - \\
27 & F & 20 & Infectious & $3 \cdot 5$ & $23 \cdot 4$ & 480 & - \\
28 & F & 31 & Behçet's & $2 \cdot 0$ & $1 \cdot 0$ & 2 & + \\
29 & M & 36 & Gouty & $4 \cdot 9$ & $20 \cdot 1$ & 360 & - \\
& M & 41 & Gouty & $5 \cdot 5$ & $23 \cdot 1$ & 480 & - \\
\hline
\end{tabular}

NT $=$ Not tested

Table III Total protein concentrations and complement activities in synovial fluids of 19 rheumatoid arthritis patients (Nos 30-48)

\begin{tabular}{|c|c|c|c|c|c|c|}
\hline Case No. & Sex & $\begin{array}{l}\text { Age } \\
(y r s)\end{array}$ & $\begin{array}{l}\text { Total protein } \\
\text { concentration } \\
(\mathrm{mg} . / 100 \mathrm{ml} .)\end{array}$ & $\mathrm{CH}_{50}$ & $I A_{60}$ & $\begin{array}{c}\text { Latex-fixation } \\
\text { test }\end{array}$ \\
\hline $\begin{array}{l}30 \\
31 \\
32 \\
33 \\
34 \\
35 \\
36 \\
37 \\
38 \\
39 \\
40 \\
41 \\
42 \\
43 \\
44 \\
45 \\
46 \\
47 \\
48\end{array}$ & $\begin{array}{l}M \\
F \\
F \\
F \\
F \\
M \\
F \\
F \\
F \\
F \\
F \\
F \\
F \\
M \\
M \\
M \\
F \\
F \\
F\end{array}$ & $\begin{array}{l}51 \\
48 \\
32 \\
41 \\
55 \\
46 \\
34 \\
51 \\
56 \\
43 \\
47 \\
50 \\
40 \\
42 \\
42 \\
43 \\
43 \\
52 \\
25\end{array}$ & $\begin{array}{l}4 \cdot 6 \\
4 \cdot 9 \\
3 \cdot 6 \\
3 \cdot 6 \\
2 \cdot 0 \\
5 \cdot 0 \\
3 \cdot 1 \\
4 \cdot 9 \\
4 \cdot 7 \\
1 \cdot 9 \\
4 \cdot 5 \\
1 \cdot 6 \\
3 \cdot 5 \\
3 \cdot 6 \\
4 \cdot 1 \\
5 \cdot 3 \\
5 \cdot 1 \\
2 \cdot 6 \\
4 \cdot 9\end{array}$ & $\begin{array}{l}1 \\
1 \cdot 0 \\
2 \cdot 0 \\
2 \cdot 6 \\
1 \\
1 \\
2 \cdot 8 \\
1 \cdot 0 \\
1 \\
2 \cdot 0 \\
1 \\
2 \cdot 0 \\
1 \\
14 \cdot 0 \\
14 \cdot 0 \\
16 \cdot 0 \\
27 \cdot 0 \\
10 \cdot 0 \\
17 \cdot 5\end{array}$ & $\begin{array}{r}2 \\
2 \\
5 \\
5 \\
2 \\
2 \\
5 \\
2 \\
2 \\
8 \\
2 \\
8 \\
2 \\
240 \\
240 \\
240 \\
720 \\
80 \\
480\end{array}$ & $\begin{array}{l}+ \\
++ \\
++ \\
+ \\
++ \\
+ \\
+ \\
+ \\
++ \\
+ \\
+ \\
+ \\
+ \\
+ \\
++ \\
++ \\
+ \\
+ \\
+ \\
+ \\
+ \\
+\end{array}$ \\
\hline
\end{tabular}

Relationship between complement activity and total protein concentration in synovial fluid

The relationship between complement activity and total protein concentration in synovial fluid was illustrated in Fig. 1.

Most of the protein values in synovial fluid of osteoarthritis were less than $3.5 \mathrm{~g} . / 100 \mathrm{ml}$. and the complement values were intermediate.

In other non-rheumatic conditions, the degree of

FIG. 1 Relationship between total protein concentrations and haemolytic complement activities in synovial fluids.

Other includes traumatic, infectious, Behçet's, and gouty arthritis.

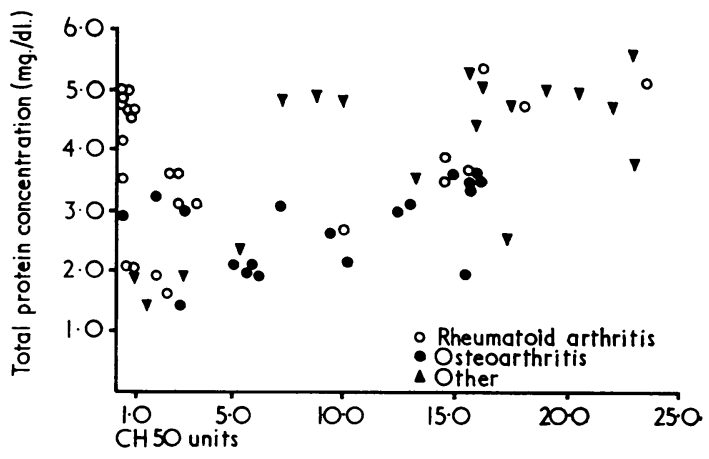


inflammation was reflected in the synovial fluid protein concentration, which was generally high and approached that of serum level. Complement activities were also high in these synovial fluids.

In rheumatic arthritis, although the protein concentrations were elevated over a range similar to that of gout and other types of acute arthritis, the synovial fluid complement values were lower than those of osteoarthritis and not related to the amount of protein present in synovial fluid. These results suggest the utilization of complement system in affected joint spaces of rheumatoid arthritis.
Complement components in synovial fluid

The depletion of complement activity in rheumatic synovial fluid indicates that at least one of the nine complement components in these fluids lacks of its haemolytic activity. Therefore, reactivity of each components of complement was measured in rheumatic and osteoarthritic synovial fluids. As shown in Tables IV and V, the results indicated that $\mathrm{C4}$ reactivity was strikingly low in rheumatic as compared with in osteoarthritic synovial fluid.

Although there were some diminutions in the activities of most components, especially C2, C3,

Table IV Complement components in synovial fluids of seventeen osteoarthritis patients (Nos 1-17)

\begin{tabular}{lrrrrrrrrr}
\hline Case No. & $C 1$ & \multicolumn{1}{c}{$C 4$} & $C 2$ & $C 3$ & $C 5$ & $C 6$ & $C 7$ & \multicolumn{1}{c}{$C 8$} & \multicolumn{1}{c}{$C 9$} \\
\hline 1 & 9,000 & 1,000 & 2,000 & 350 & 1,000 & 3,000 & 3,000 & 4,000 & 4,000 \\
2 & 50 & 1,000 & 350 & 350 & 125 & 50 & 125 & 12,000 & 12,000 \\
3 & 8,000 & 700 & 1,000 & 350 & 1,000 & 1,000 & 1,000 & 1,000 & 1,000 \\
4 & 8,000 & 1,000 & 350 & 350 & 1,000 & 350 & 3,000 & 4,000 & 4,000 \\
5 & 9,000 & 700 & 1,000 & 350 & 1,000 & 350 & 1,000 & 2,000 & 4,000 \\
6 & 12,000 & 700 & 1,000 & 1,000 & 2,000 & 1,000 & 3,000 & 12,000 & 4,000 \\
7 & 50 & 1,000 & 350 & 350 & 125 & 1,000 & 2,000 & 4,000 & 12,000 \\
8 & 12,000 & 4,000 & 2,000 & 1,000 & 1,000 & 2,000 & 3,000 & 4,000 & 4,000 \\
9 & 12,000 & 27,000 & 2,000 & 350 & 1,000 & 1,000 & 3,000 & 4,000 & 4,000 \\
10 & 9,000 & 3,000 & 350 & 350 & 350 & 125 & 125 & 12,000 & 12,000 \\
11 & 8,000 & 2,000 & 1,000 & 350 & 125 & 350 & 1,000 & 4,000 & 12,000 \\
12 & 9,000 & 1,000 & 1,000 & 350 & 1,000 & 1,000 & 3,000 & 2,000 & 4,000 \\
13 & 8,000 & 4,000 & 350 & 125 & 125 & 350 & 3,000 & 4,000 & 8,000 \\
14 & 350 & 350 & 700 & 125 & 125 & 1,000 & 3,000 & 4,000 & 12,000 \\
15 & 8,000 & 3,000 & 700 & 350 & 700 & 1,000 & 3,000 & 8,000 & 12,000 \\
16 & 9,000 & 3,000 & 350 & 350 & 350 & 125 & 125 & 12,000 & 12,000 \\
17 & 9,000 & 4,000 & 2,000 & 350 & 700 & 1,000 & 3,000 & 4,000 & 8,000 \\
\hline Normal & & & & & & & & & \\
human & 32,000 & 120,000 & 8,000 & 3,200 & 3,000 & 6,000 & 12,000 & 30,000 & 50,000 \\
serum & & & & & & & & & \\
\hline
\end{tabular}

Table V Complement components in synovial fluids of 19 rheumatoid arthritis patients (Nos 30-48)

\begin{tabular}{|c|c|c|c|c|c|c|c|c|c|}
\hline Case No. & $C 1$ & $C 4$ & $C 2$ & $C 3$ & $C 5$ & $C 6$ & $C 7$ & $C 8$ & $C 9$ \\
\hline $\begin{array}{l}30 \\
31 \\
32 \\
33 \\
34 \\
35 \\
36 \\
37 \\
38 \\
39 \\
40 \\
41 \\
42 \\
43 \\
44 \\
45 \\
46 \\
47 \\
48\end{array}$ & $\begin{array}{r}1,000 \\
3,000 \\
700 \\
700 \\
350 \\
50 \\
350 \\
70 \\
1,000 \\
9,000 \\
3,000 \\
3,000 \\
1,000 \\
3,000 \\
9,000 \\
8,000 \\
8,000 \\
1,000 \\
9,000\end{array}$ & $\begin{array}{r}2 \\
125 \\
50 \\
50 \\
2 \\
2 \\
50 \\
2 \\
125 \\
9,000 \\
2 \\
125 \\
2 \\
2,000 \\
3,000 \\
9,000 \\
3,000 \\
700 \\
3,000\end{array}$ & $\begin{array}{r}125 \\
1,000 \\
1,000 \\
125 \\
125 \\
125 \\
350 \\
200 \\
350 \\
2,000 \\
125 \\
700 \\
350 \\
3,000 \\
2,000 \\
8,000 \\
4,000 \\
350 \\
350\end{array}$ & $\begin{array}{r}1,000 \\
1,000 \\
350 \\
700 \\
350 \\
200 \\
350 \\
350 \\
700 \\
350 \\
350 \\
1,000 \\
700 \\
1,000 \\
2,000 \\
1,000 \\
350 \\
350 \\
350\end{array}$ & $\begin{array}{r}1,000 \\
1,000 \\
350 \\
700 \\
700 \\
350 \\
350 \\
300 \\
700 \\
1,000 \\
1,000 \\
125 \\
700 \\
2,000 \\
2,000 \\
700 \\
125 \\
700 \\
125\end{array}$ & $\begin{array}{r}700 \\
125 \\
350 \\
350 \\
125 \\
125 \\
700 \\
125 \\
1,000 \\
350 \\
125 \\
125 \\
1,000 \\
3,000 \\
2,000 \\
1,000 \\
1,000 \\
1,000 \\
1,000\end{array}$ & $\begin{array}{l}3,000 \\
1,000 \\
1,000 \\
1,000 \\
2,000 \\
1,000 \\
2,000 \\
1,000 \\
3,000 \\
3,000 \\
3,000 \\
2,000 \\
2,000 \\
4,000 \\
4,000 \\
2,000 \\
4,000 \\
2,000 \\
2,000\end{array}$ & $\begin{array}{r}4,000 \\
4,000 \\
4,000 \\
2,000 \\
3,000 \\
12,000 \\
4,000 \\
12,000 \\
4,000 \\
12,000 \\
4,000 \\
4,000 \\
2,000 \\
4,000 \\
12,000 \\
2,000 \\
4,000 \\
4,000 \\
8,000\end{array}$ & $\begin{array}{r}8,000 \\
4,000 \\
8,000 \\
4,000 \\
8,000 \\
4,000 \\
8,000 \\
12,000 \\
8,000 \\
12,000 \\
4,000 \\
4,000 \\
8,000 \\
8,000 \\
12,000 \\
8,000 \\
12,000 \\
4,000 \\
8,000\end{array}$ \\
\hline $\begin{array}{l}\text { Normal } \\
\text { human } \\
\text { serum }\end{array}$ & 32,000 & 120,000 & 8,000 & 3,200 & 3,000 & 6,000 & 12,000 & 30,000 & 50,000 \\
\hline
\end{tabular}


C5, and C6, these were far less remarkable than in the case of C4. It was therefore concluded that the low complement reactivity of rheumatoid synovial fluids was mainly due to the depletion of C4 activity.

\section{Immunoelectrophoretic analysis of C4 in synovial fluid}

$\mathrm{C} 4$ is said to have antigenic property as $\beta_{1 \mathrm{E}}$ globulin. $\beta_{1 \mathrm{E}}$ globulin was therefore tested immunoelectrophoretically using eight cases of synovial fluids with low C4 reactivity.

In one out of eight cases of rheumatoid arthritis (Case 31), $\beta_{1 \mathrm{E}}$ globulin precipitin line was hardly observed, indicating the depletion of this substance. But the other seven cases showed distinct $\beta_{1 \mathrm{E}}$ precipitin lines as well as the normal control serum, indicating the adequate amount of $\beta_{1 \mathrm{E}}$ globulin in these synovial fluids (Fig. 2).

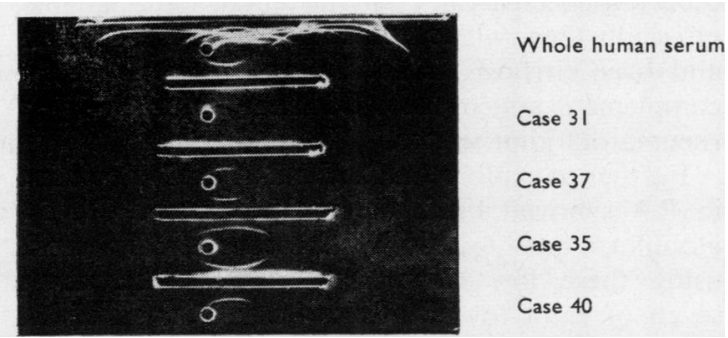

FIG. $2 \beta_{1 \mathrm{E}}$ globulin in synovial fluids of rheumatoid arthritis. Four cases out of eight are presented. Fresh synovial fluids were taken into 0.02 M EDTA solution (final concentration pH 7-2).

Upper trough: Horse anti-whole human serum (Osaka Microbial Diseases Research Foundation, Lot No. 6).

Other troughs: Anti- $\beta_{1 \mathrm{E}}$ globulin rabbit serum.

Semiquantitative measurements of $\beta_{1 \mathrm{E}}$ globulin were performed using the double diffusion method. Serial dilutions of synovial fluids from rheumatoid arthritis and osteoarthritis were made, and the maximum dilutions which produced the distinct precipitin line were determined. No differences were observed in the amounts of $\beta_{1 \mathrm{E}}$ globulin in each synovial fluid (Table VI). From these observations, it appears that many parts of $\beta_{1 E}$ globulin in rheumatoid synovial fluids are changed to a haemolytically inactive form.

\section{Measurement of $\beta_{1 \mathrm{c}}\left(\beta_{1 \mathrm{~A}}\right)$ globulin}

The $\beta_{1 \mathrm{c}}$ globulin is said to have a close relationship with C3. The amounts of $\beta_{1 \mathrm{C}}$ antigenicity were therefore measured using Partigen plates. As shov. $n$ in Fig. 3, the $\beta_{1 \mathrm{c}}$ antigenicity had a good correlation with $\mathrm{C} 3$ activity in non-RA fluids. But in RA fluids, C3 activities were rather low in spite of the high levels of $\beta_{1 \mathrm{c}}$ antigenicity. This result indicates that in RA fluids many parts of $\beta_{1 \mathrm{c}}$ globulin exist in an inactivated form.
Table VI $\beta_{1 \mathrm{E}}$ globulin and C4 activities in synovial fluids of eight rheumatoid arthritis and five osteoarthritis patients

\begin{tabular}{llrr} 
Case No. & Diagnosis & $\beta_{1 \mathrm{E}}$ globulin $^{*}$ & \multicolumn{1}{l}{$C 4$} \\
\hline 30 & RA & 32 & 2 \\
31 & RA & 8 & 125 \\
34 & RA & 32 & 2 \\
35 & RA & 32 & 2 \\
37 & RA & 16 & 2 \\
38 & RA & 32 & 4 \\
40 & RA & 32 & 2 \\
42 & RA & 32 & 4 \\
\hline 1 & OA & 32 & 1,000 \\
2 & OA & 32 & 1,000 \\
3 & OA & 32 & 700 \\
9 & OA & 32 & 21,000 \\
10 & OA & 16 & 3,000 \\
\hline Control & Fresh & 32 & 120,000 \\
& normal & & \\
& human & &
\end{tabular}
$* \beta_{1 E}$ globulin was measured using Ouchterlony's method. The
number showed the reciprocal of maximum dilution which gave visible precipitin.

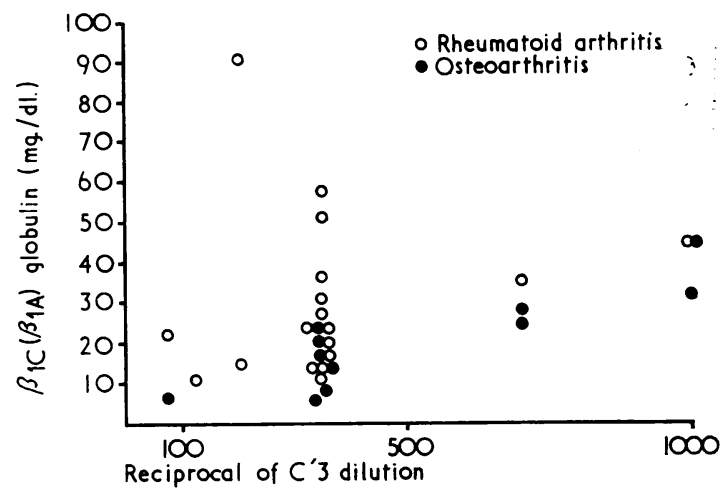

FIG. 3 Relationship between $C 3$ activity and $\beta_{1 \mathrm{C}}\left(\beta_{1 \mathrm{~A}}\right)$ globulin amount in synovial fluids. Fresh synovial fluids were taken into $0.02 M E D T A$ solution (final concentration $\mathrm{pH} 7 \cdot 2$ ).

\section{Immunoelectrophoretic analyses of $C 3$ in synovial fluid}

$\beta_{1 \mathrm{c}}$ globulin is converted to $\beta_{1 \mathrm{~A}}$ globulin, an inactivated form, on storage or in an immunological reaction, and the $\beta_{1 \mathrm{~A}}$ globulin is readily distinguished from the $\beta_{1 \mathrm{c}}$ globulin by immune electrophoresis (Müller-Eberhard and Nilsson, 1960). Some synovial fluids from patients with rheumatic arthritis and osteoarthritis were therefore tested immunoelectrophoretically against anti-C3 rabbit serum. For this experiment, all synovial fluids were taken into $0.02 \mathrm{M}$ EDTA (final concentration) to. interrupt conversions during storage.

All samples showed the existence of both $\beta_{1 \mathrm{C}}$ and $\beta_{1 \mathrm{~A}}$. globulin. However, in rheumatoid arthritis (Case 35 ), 
$\beta_{1 \mathrm{~A}}$ globulin appeared in greater quantity than $\beta_{1 \mathrm{C}}$ globulin as compared with osteoarthritis (Case 1) (Fig. 4). This report supports the concept that, in the affected joint spaces, C3 is used and inactivated in cases of rheumatoid arthritis.

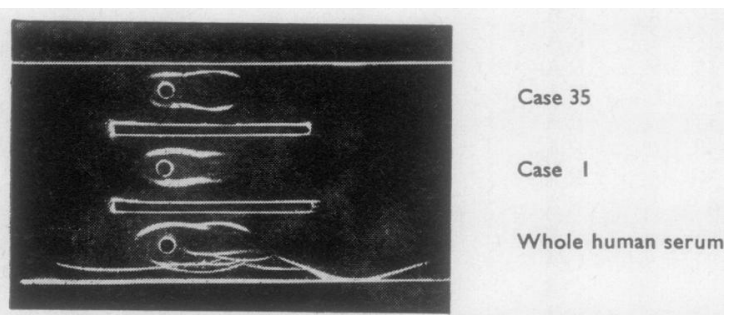

FIG. $4 \beta_{1 \mathrm{C}}$ globulin in synovial fluids of rheumatoid arthritis (Case 35) and osteoarthritis (Case 1). Fresh synovial fluids were taken into $0.02 \mathrm{M}$ EDTA solution (final concentration $\mathrm{pH} 7 \cdot 2$ ).

Normal whole human serum was stored at $-70^{\circ} \mathrm{C}$. for about 2 months.

Upper trough: Anti- $\beta_{1 \mathrm{C}}$ globulin rabbit serum.

Middle trough: Anti- $\beta_{1} \mathrm{C}$ globulin rabbit serum.

Lower trough: Horse anti-whole human serum (Osaka Microbial Diseases Research Foundation, Lot No. 6).

\section{Latex-fixation test (LFT) of synovial fluids}

The results of the LFT are shown in Table I, II, and III. No relationship between complement activity and LFT titre was observed.

\section{Discussion}

It is said that in rheumatoid arthritis the level of serum complement is slightly elevated, whereas the titre in joint effusions is strikingly diminished in comparison with other joint diseases (Pekin and Zvaifler, 1964; Hedberg, 1963). Our observations support these findings: the concentration of 6-12 $\mathrm{CH}_{50}$ units per ml. synovial fluid in thirteen patients with osteoarthritis was roughly one-fourth the serum $\mathrm{CH}_{50}$ concentration, which is $36 \cdot 43 \pm 5 \cdot 47$ (Torisu, Arata, and Majima, 1966). The synovial fluid $\mathrm{CH}_{50}$ levels in cases of acute arthritis, such as gouty or post-traumatic arthritis, were higher. The concentration of 0-3 $\mathrm{CH}_{50}$ units was much lower in synovial fluids from thirteen patients with rheumatoid arthritis.

Like Pekin and Zvaifler (1964) and Hedberg (1963) we found a direct relationship between the protein concentration and the complement activity of synovial fluid from non-rheumatoid joint diseases. But the complement activity in rheumatoid fluids did not correlate with the protein concentration as is shown in Fig. 1. This seems to suggest that the rheumatoid factor has an anticomplementary activity, but no relationship between rheumatoid factor and haemolytic complement activity was observed in the present study. Therefore, rheumatoid factor could not be held to account for the depletion of complement activity in synovial fluids from rheumatic patients.

In order to explore the mechanism of this apparent intra-articular complement depletion in RA, measurements of nine components of complement were performed. The result indicated that $\mathrm{C4}$ was strikingly low as compared with other complement components (Table V). Some diminutions in the activity of $\mathrm{C} 2, \mathrm{C} 3, \mathrm{C} 5, \mathrm{C} 6$ were also observed, but these were much less marked. The lowered total haemolytic complement activity in RA synovial fluid was thus accounted for by the low activity of C4. It is known that C4 is the complement component which is most depleted by the complementfixation test.

Inai, Fujikawa, Nagaki and Takahashi (1967) reported a decrease in $\mathrm{C} 4$ in the sera of some patients, especially those with chronic myelogenous leukaemia and liver cirrhosis. This finding suggests that the complement system loses its haemolytic activity in rheumatoid joint spaces.

Further to explore the mechanism of $\mathrm{C} 4$ depletion in RA synovial fluid, the antigenicity of $\mathrm{C4}, \beta_{1 \mathrm{E}}$ globulin, was tested by immunoelectrophoresis using these low $\mathrm{C} 4$ fluids. As described above seven of eight low $\mathrm{C} 4$ fluids gave clear precipitin lines against anti- $\beta_{1 \mathrm{E}}$ rabbit serum, indicating the existence of high levels of $\beta_{1 \mathrm{E}}$ globulin. These results were confirmed by semiquantitative measurements (Table VI). This result shows that $\mathrm{C} 4$ can enter into the joint spaces in RA. but loses its activity and exists in an inactivated form; i.e. treatment of $\mathrm{C} 4$ with $\mathrm{Cl}$ esterase results in its conversion to the haemolytically inactive product $\mathrm{C4i}$ (MüllerEberhard and Lepow, 1965). One case out of eight gave only a faint precipitin line, showing a marked diminution of $\beta_{1 \mathrm{E}}$ globulin. Fostiropoulos, Austen, and Block (1965) reported that $\beta_{1 \mathrm{E}}$ globulin was so diminished in RA synovial fluid that it was hardly detectable in the fluid of seven cases. This discrepancy between their observations and ours may be due to a difference in sensitivity of the detection method. On the other hand, Hiramatsu, Nagaki, Inai, and Tanabe (1967) reported that the $\beta_{1 \mathrm{E}}$ precipitin line in whole human serum did not change its immunoelectrophoretic properties before and after treatment with immune precipitates. It is thus conceivable that $\beta_{1 E}$ precipitin lines exist even if $C 4$ activity is very low.

Fostiropoulos and others (1965) reported that many synovial fluids contained both $\beta_{1 \mathrm{~A}}$ and $\beta_{1 \mathrm{c}}$ globulin, so that C3 was not the 'limiting factor' of the low complement synovial fluids. Our results support this, but a more important finding was that a higher level of $\beta_{1 \mathrm{~A}}$ globulin was present in RA synovial fluids than in osteoarthritic fluids (Fig. 4). 
$\beta_{1 \mathrm{C}}\left(\beta_{1 \mathrm{~A}}\right)$ antigenicity was measured in some synovial fluids by using Partigen plates. As described above (Fig. 3), the $\beta_{1 \mathrm{c}}\left(\beta_{1 \mathrm{~A}}\right)$ antigenicity had a good correlation with $\mathrm{C} 3$ activity in non-RA fluids, but was relatively low in RA fluids. This indicates that in RA fluids some parts of $\mathrm{C} 3$ exist in an inactivated form, and suggests that the complement system is utilized in the inflammatory processes.

\section{Summary}

Total haemolytic complement activity is relatively low in synovial fluids from patients with rheumatoid arthritis despite the high concentrations of total protein.

The presence of nine components of complement in synovial fluids was demonstrated.

The activity of the fourth complement component (C4) was much lower in synovial fluid from rheumatoid arthritis patients than in fluids from patients with degenerative joint disease. However, the levels of $\beta_{1 \mathrm{E}}$ globulin in these fluids with a low $\mathrm{C} 4$ component were not so low as might be expected, indicating the presence of an inactivated form of $\mathrm{C4}$ in such fluids.

The level of $\beta_{1 \mathrm{c}}$ globulin in synovial fluids was measured using Partigen's immunoplates. A discrepancy between $\mathrm{C} 3$ activity and the amount of $\beta_{1 \mathrm{c}}\left(\beta_{1 \mathrm{~A}}\right)$ globulin was observed in fluids from rheumatoid arthritis patients. These results indicate higher amounts of inactivated C3 ( $\beta_{1 \mathrm{~A}}$ globulin) in synovial fluid from rheumatoid patients than in fluid from cases of degenerative joint disease. These observations indicate that these complement components are utilized in the joint spaces of patients with rheumatoid arthritis.

We are grateful to Drs. K. Tanimoto, M. Higashi M. Matsuura, S. Takizawa, and S. Shiraishi for their collaboration, to Drs. K. Nishioka and J. Matsumoto for valuable discussions, and to Miss $\mathrm{K}$. Yoshikawa for technical assistance.

\section{References}

Borsos, T., Dourmashin, R. R., AND Humphrey, J. H. (1964) Nature (Lond.), 202, 251 (Lesions in erythrocyte membranes caused by immune haemolysis).

COOPER, N. R., AND BECKER, E. L. (1967) J. Immunol., 98, 119 (Complement associated peptidase activity of guinea-pig serum).

DiAS DA SILVA, W., AND LePOW, I. H. (1956) Ibid., 95, 1080 (Anaphylatoxin formation by purified human C1 esterase).

- (1966) Immunochemistry, 3, 497 (Properties of anaphylatoxin prepared from purified components of human complement). (Abstr.)

Fostiropoulos, G., Austen, K. F., AND Bloch, K. J. (1965) Arthr. and Rheum., 8, 219 (Total hemolytic complement $\left(\mathrm{CH}_{50}\right)$ and second component of complement $\left(\mathrm{C}^{\mathrm{hu}}\right)$ activity in serum and synovial fluid).

Green, H., Barrow, P., AND GoldberG, B. (1959) J. exp. Med., 110, 699 (Effect of antibody and complement on permeability control in ascites tumor cells and erythrocytes).

Hedberg, H. (1963) Acta rheum. scand., 9, 165 (Studies on the depressed hemolytic complement activity of synovial fluid in adult rheumatoid arthritis).

Hiramatsu, S., NAgaki, K., InaI, S., AND TANabe, S. (1967) Biken's Journal. 10, 175 (Immunoelectrophoretic studies on $\beta_{1 \mathrm{E}}$ globulin in human serum).

Inai, S., Fujikawa, K., Nagaki, K., and TaKahashi, H. (1967) Ibid., 10, 65 (Serum level of the fourth component of complement in various diseases).

InOUE, K., AND Nelson, R. A. (1965) J. Immunol., 95, 355 (The isolation and characterization of a new component of hemolytic complement, $\left.C^{\prime} 3 \mathrm{e}\right)$.

JeNSEN, J. (1967) Science, 155, 1122 (Anaphylatoxin in its relation to the complement system).

Lepow, I. H., Ratnoff, O. D., Rosen, F. S., And Pillemer, L. (1966). Proc. Soc. exp. Biol. (N.Y.), 92, 32 (Observations on a proesterase associated with partially purified first component of human complement).

MAYER, M. M. (1961) 'Complement and complement fixation,' in 'Experimental Immunochemistry', 2nd ed., ed. E. A. Kabat and M. M. Mayer chap. 4, p. 135. Thomas, Springfield, Ill.

Müller-Eberhard, H. J. (1965) In 'Bacterial and Mycotic Infections of Man', 4th ed., ed. R. J. Dubos and J. G. Hirsch, p. 181. Lippincott, Philadelphia.

- AND BiRo, C. E. (1963) J. exp. Med., 118, 447 (Isolation and description of the fourth component of human complement).

- AND LePOW, I. H. (1965) Ibid., 121, 819 (C'1 esterase effect on activity and physico-chemical properties of the fourth component of complement).

- AND Nilsson, U. R. (1960) Ibid., 111, 217 (Relation of a $\beta_{1}$-glycoprotein to the complement system of human serum).

- Polley, M. J., AND Calcott, M. A. (1967) Ibid., 125, 359 (Formation and functional significance of a molecular complex derived from the second and the fourth component of human complement).

MusCheL, L. H., AND TREFFERS, H. P. (1956) J. Immunol., 76, 11 (Quantitative studies on the bactericidal actions of serum and complement. II. Some implications for the mechanism of the bactericidal reaction). 
Nelson, R. A., JR. (1953) Science, 118, 733 (The immune-adherence phenomenon. An immunologically specific reaction between microorganisms and erythrocytes leading to enhanced phagocytosis).

- Jensen, J., Gigli, I., AND TAmURA, N. (1966) Immunochemistry, 3, 111 (Methods for the separation, purification and measurement of nine components of hemolytic complement in guinea-pig serum).

NishiokA, K. (1963) J. Immunol., 90, 86 (Measurements of complement by agglutination of human erythrocytes reacting in immune-adherence).

- AND LinscotT, W. D. (1963) J. exp. Med., 118, 767 (Components of guinea-pig complement. I. Separation of a serum fraction essential for immune hemolysis and immune adherence).

Pexin, T. J., ANd Zvaifler, N. J. (1964) J. clin. Invest., 43, 1372 (Hemolytic complement in synovial fluid).

Shimada, K., Sexine, T., Mayumi, M., and Miyakawa, Y. (1969) J. Immunol., 102, 1338 (Separation and function of the fourth component of complement). (Abstr.)

ScheidegGer, J. J. (1955) Int. Arch. Allergy, 7, 103 (Une micro-méthode de l'immuno-électrophorèse).

Tamura, N., and Jensen, J. (1966) Immunochemistry, 3, 504 (Purified components of guinea-pig complement: Reaction of erythrocytes with antibody and the first four components).

Torisu, M., Arata, M., AND Majima, H. (1966) Jap. J. exp. Med., 36, 251 (Low reactivity of human complement in healthy adults).

- - Sonozaki, H., AND MaJima, H. (1967) J. Immunol., 99, $629\left(\mathrm{C}^{\prime} 3 \mathrm{c}\right.$ deficient human sera with a $\beta_{1 \mathrm{C}}$ precipitin line).

—-, Sonozaki, H., Shiraishi, S., ANd Nishioka, K. (1968) Nature (Lond.), 218, 1163 (Purification of C'3 inactivator from human serum).

Ward, P. A., Cochrane, C. G., AND Müller-Eberhard, H. J. (1966) Immunology, 11, 141 (Further studies on the chemotactic factor of complement and its formation in vivo).

\section{RÉSUMÉ}

Le complément dans les liquides synoviaux des malades atteints d'arthrite rhumatoide.

L'activité hémolytique totale du complément est relativement basse dans le liquide synovial chez les malades atteints d'arthrite rhumatoïde malgré les hautes concentrations de toutes les protéines.

La présence de neuf parties constituantes dans le liquide synovial a été démontrée.

L'activité de la quatrième partie constituante du complément (C4) était beaucoup plus basse dans le liquide synovial des malades atteints d'arthrite rhumatoïde que dans celui des malades atteints de maladie des articulations causée par la dégénérescence. Cependant les niveaux de globuline $\beta_{1 \mathrm{E}}$ dans ces liquides ayant une partie constituante (C4) basse n'étaient pas aussi bas qu'on aurait pu s'attendre, indiquant ainsi la présence d'une forme inactive de $\mathrm{C} 4$ dans ces liquides.

Le taux de la globuline $\beta_{1 \mathrm{C}}$ dans les liquides synoviaux a été estimé par les immunoplaques de Partigen. Une divergence entre l'activité du $\mathrm{C} 3$ et la quantité de la globuline $\beta_{1 \mathrm{C}}\left(\beta_{1 \mathrm{~A}}\right)$ a été observée dans les liquides provenant des malades atteints d'arthrite rhumatoïde. Ces résultats indiquent des quantités plus élévées de $\mathrm{C} 3$ inactif (globuline $\beta_{1 \mathbf{A}}$ ) dans le liquide snyovial des malades atteints d'arthrite rhumatoïde que dans le liquide obtenu des cas de maladies articulaires causées par la dégénérésence. Ces observations indiquent que ces parties constituantes du complément sont utilisées dans les espaces articulaires des malades atteir.ts d'arthrite rhumatoỉde.
SUMAR I O

Estudios del ccmplemento en fluidos sinoviales de pacientes con poliartritis reumatoide

La actividad del complemento hemolítico absoluto se halla relativamente baja en los fluidos sinoviales de pacientes con poliartritis reumatoide, a pesar de las altas concentraciones de proteína absoluta.

Se demostró la presencia de nueve componentes en los fluidos sinoviales.

La actividad del cuarto componente de complemento (C4) fue mucho más baja en el fluido sinovial de pacientes con poliartritis reumatoide que en fluidos de pacientes con enfermedad articular degenerativa. No obstante, los niveles de globulina $\beta_{1 \mathrm{E}}$ en estos fluidos con ejcaso componente $\mathrm{C} 4$ no eran tan bajos como podría esperarse, lo cual indicaba la presencia de una forma inactivada de $\mathrm{C} 4 \mathrm{en}$ tales fluidos. El nivel de globulina $\beta_{\text {: }}$ en los fluidos sinoviales fue medido usando inmunoplacas de partígeno. Se observó una discrepancia entre la actividad del C3 y la cantidad de globulina $\left.\beta . c^{\prime} \beta_{1 A}\right)$ en fluidos de pacientes con poliartritis reumatoide. Estos resultados señalan la presencia de más altas cantidades de $\mathrm{C} 3$ (globulina $\beta_{1 \mathrm{~A}}$ ) inactivado en fluido sinovial de pacientes reumatoides, que en fluido de casos de enfermedad articular dezenerativa. Estas observaciones indican que estos componentes de complemento son utilizados en los espacios articulares de pacientes con poliartritis reumatoide. 